\title{
COMMENTARY
}

\section{Hemp: Can cooperative-run quotas prevent overproduction?}

\author{
Chad Hellwinckel * \\ University of Tennessee
}

Submitted August 12, 2019 / Accepted August 12, 2019 / Published online January 22, 2020

Citation: Hellwinckel, C. (2020). Hemp: Can cooperative-run quotas prevent overproduction?. Journal of Agriculture, Food Systems, and Community Development, 9(2), 9-11. https://doi.org/10.5304/jafscd.2020.092.016

Copyright $(\mathcal{C} 2020$ by the Author. Published by the Lyson Center for Civic Agriculture and Food Systems. Open access under CC-BY license.

$\mathrm{T}$ he legalization of hemp provides a new opportunity for small farmers in the U.S., and coming on the heels of trade wars and depressed crop returns, the timing couldn't be better. However, while hemp production could support a decent living for these small farmers, production opportunities such as this will draw interest from producers of all sizes, which may determine its profitability. Hemp, just like any other crop, can be produced on a massive scale. The industrial system stands at the ready with machines, inputs, land-grant agricultural research universities, transportation systems, markets, and capital to plant hemp on large acreages and then process, market, and deliver it to consumers. Once unleashed, the vast majority of the crop could be grown on large acreages under industrial management, mechanized, and with few people on the land. Organic hemp could be another option offered by the industrial model, but could be equally mechanized. Within five to 10

* Chad Hellwinckel, Research Associate Professor, University of Tennessee; 2621 Morgan Circle Drive; Knoxville, TN 37996 USA; chellwin@utk.edu years, any current profit advantage of hemp to farmers could diminish to the low level of market returns offered by other industrial crops like corn or beans.

Today, new hemp farmers are able to do what they love and make a living doing it. These farmers are truly building an ideal agrarian life, often producing organically on small acreages while integrating other crops on the farm, raising families on the land, improving the local ecology, and being good neighbors. Many of these farmers see their work as an art form - caring for the earth, the soil, and all the inhabitants of their unique corner of the universe. Profitable, small ecological farms are a welcomed emergence in rural areas where good news has been scarce for decades. Hopefully, they persist and more farmers are able to tend to small acreages. Yet the history and nature of agriculture teach that this bright future will only be attainable if we insist upon prices that cover the costs of production and a cooperative system that assures that small hemp farmers will always receive a fair price for their crop. 
The tobacco quota system that supported small-scale rural farmers from the 1930s until about 2000 provides a good model for hemp growers. The tobacco system functioned by the federal government granting the sole right to sell tobacco to farmer cooperatives. Cooperative members voted every three years to determine if they wanted price support. If so (and they always voted yes), they were subject to a quota system limiting their level of production to that which would return a living wage to all members of the tobacco cooperative. Members of the cooperatives received "quotas" or rights to bring a certain amount of crop to market. The program worked by limiting supply and thereby raising the market price above what it would be under all-out freemarket production. The program was mostly selffunded, with minimal cost to taxpayers (Womach, 2005). Consumers of tobacco paid a slightly higher price, and this higher price allowed farmers to make a living on small plots of land. For example, in Kentucky, tobacco made up only $1 \%$ of cropland but accounted for about $50 \%$ of total crop income (Snell \& Goetz, 1997). It kept small farmers in business and, in turn, kept small-town economies healthy.

In 2004, the program ended through a buyout by the tobacco industry due to the decrease in domestic tobacco demand and tobacco companies importing greater amounts from other countries. Since the buyout, farmers are free to produce as much as they want. Not surprisingly, tobacco farmers in the hilly, forested, rural areas of Appalachia-where the geography is not conducive to massive machinery-could not compete. The vast majority of tobacco in the U.S. is now grown in the flat country on the Atlantic coastal plains. Instead of 1 to 5 acres ( 0.4 to 2 hectares) of production supporting a farm family, you now see thousandacre (405 ha) fields under mechanization. Small Appalachian rural economies have collapsed. It may be no coincidence that the opioid epidemic has exploded in old tobacco country since the quota system buyout in 2004.
Today, some hemp farmers believe that the expanding market can support unlimited numbers of growers, and they do not want any constraints on the growing or selling of hemp. I think we need to pause and take a circumspect look at the problem of overproduction in agriculture that has been in the nature of agriculture for the past century, rather than letting these boom times cloud our view of reality. Technology, mechanization, and the inability of any one farmer to control market supply has consistently driven the market price of crops below the cost of production, leading to cycles of farmer bankruptcies and consolidations. Overproduction is in the nature of modern technological agriculture, and it cannot be solved without an agreed-upon system of production controls (Ray, De La Torre Ugarte, \& Tiller, 2003).

Hemp is a new crop not yet in the hands of industrial growers. New farmers and conscientious consumers should take steps now to devise a cooperative-run quota system that would assure fair prices for small hemp farmers now and into the future. Because the federal law that reestablished hemp requires individual states to regulate hemp, ideally states could establish supply control quota systems within their borders to ensure the benefits of the new crop are directed toward small farms. If state or national governments cannot act, then private cooperatives can also be fairly effective. For example, in the dairy industry, Organic Valley, a farmer-owned cooperative, has been successful at providing higher prices to members. Organic Valley does this by sometimes limiting the quantity that each farmer can provide to assure that overproduction does not occur. However, private cooperatives only work if there is a loyal consumer base willing to pay more for the differentiated product. If full legalization continues without quota systems, prices will likely fall within a decade, the vast majority of production will be in the hands of very large corporate farms, and the potential of the crop to support agrarian life and rural prosperity will have been missed (Berry, 2016, minute 41:00).

\section{References}

Berry, W. (2016, December 13). The land, the people, and a proper economy. Lecture at the 2016 Prairie Festival, The Land Institute, Salina, Kansas. Retrieved from https://landinstitute.org/video-audio/land-people-proper-economy/ 
Ray, D. E., De La Torre Ugarte, D. G., \& Tiller, K. H. (2003). Rethinking U.S. agricultural policy: Changing course to secure farmer livelihoods worldwide. Knoxville: Agricultural Policy Analysis Center, The University of Tennessee. Retrieved from https://www.agpolicy.org/publication.htm

Snell, W., \& Goetz, S. (1997). Overview of Kentucky's tobacco economy (Report No. AEC-83). Lexington: University of

Kentucky Cooperative Extension Service. Retrieved from http://www.ca.uky.edu/agc/pubs/aec/aec83/aec83.pdf

Womach, J. (1995/2005). Tobacco price support: An overview of the program (CRS Report for Congress, 95-129).

Washington, D.C.: Congressional Research Service. Retrieved from

https://nationalaglawcenter.org/wp-content/uploads/assets/crs/95-129.pdf 